\title{
The synergistic anti-asthmatic effects of glycyrrhizin and salbutamol
}

\author{
Yang YANG ${ }^{1,2,3}$, Qian SHI ${ }^{2}$, Ze LIU ${ }^{1}$, Ruo-jie $\mathrm{LI}^{1}$, Peng-wei PAN ${ }^{1}$, Yuan-yuan HOU ${ }^{2, *}$, Wan-ge $\mathrm{LU}^{3}$, Gang BAI ${ }^{1, *}$ \\ ${ }^{1}$ College of Life Sciences, Nankai University, Tianjin 300071, China; ${ }^{2}$ College of Pharmaceutical Sciences, Nankai University, Tianjin \\ 300071, China; ${ }^{3}$ Eli and Edythe Broad Center for Regenerative Medicine and Stem Cell Research, Department of Biochemistry and \\ Molecular Biology, Graduate Program in Genetics, Molecular and Cellular Biology, University of Southern California, Los Angeles, CA \\ 90033, USA
}

\begin{abstract}
Aim: To investigate the efficacy of glycyrrhizin (GL) combined with salbutamol (SA) as an anti-asthma therapy.
Methods: Rat lung beta2-adrenergic receptor ( $\beta_{2}$-AR) mRNA level was measured by real-time RT PCR. Intracellular cAMP accumulation was evaluated with a reporter gene assay. An in vitro acetylcholine-induced guinea pig tracheal strip contraction model was used to test the relaxing effects of GL and SA. The anti-inflammatory effects of GL and SA were tested using tumor necrosis factor- $\alpha$-induced NF-kB transcriptional activation reporter assay, I-kB Western blotting and interleukin-8 ELISA. An in vivo guinea pig asthma model was used to prove further the synergistic effect of $G L$ and $S A$.

Results: GL $(0.3 \mu \mathrm{mol} / \mathrm{L})$ increased mRNA levels of $\beta_{2}-A R$ in vivo and the accumulation of cAMP in vitro. The combination of GL and SA also resulted in significant complementary anti-inflammatory effects via inhibition of NF-kB activation, degradation of I-kB and production of interleukin-8. A significant synergistic effect of the combination was detected both in vitro and in vivo in a guinea pig mode. Conclusion: The results demonstrate that GL and SA have synergistic anti-asthmatic effects and offer the possibility of a therapeutic application of $G L$ in combination with $\beta_{2}$-AR agonists in the treatment of asthma.
\end{abstract}

Keywords: asthma; $\beta_{2}$-adrenergic receptor agonists; glucocorticoids; glycyrrhizin; salbutamol; synergistic effects

Acta Pharmacologica Sinica (2010) 31: 443-449; doi: 10.1038/aps.2009.207; published online 15 Mar 2010

\section{Introduction}

Bronchial asthma is the result of smooth muscle dysfunction, airway inflammation, and airway remodeling ${ }^{[1]}$. Smooth muscle dysfunction is evidenced by exaggerated bronchoconstriction, bronchial hyper-responsiveness, hyperplasia, and hypertrophy of airway smooth muscle cells and the release of proinflammatory mediators. Beta2-adrenergic receptor $\left(\beta_{2}-A R\right)$ agonists and glucocorticoids are often used in combination in the treatment of bronchial asthma because they have distinct mechanisms of action and pathophysiological targets. When used in combination, their hypothesized interaction yields a broader activity profile than when they are used alone ${ }^{[2]}$. Glucocorticoids can increase $\beta_{2}$-AR transcription in human lung in vitro ${ }^{[3]}$ and protect pulmonary $\beta_{2}$-ARs from $\beta$-agonist-induced down-regulation in vivo ${ }^{[4]}$. Glucocorticoids can also modulate the coupling efficiency between the $\beta_{2}-A R$ and $G_{s}$ protein,

\footnotetext{
* To whom correspondence should be addressed.

E-mail gangbai@nankai.edu.cn (Gang BAl); houyy@nankai.edu.cn (Yuan-yuan HOU)

Received 2009-06-29 Accepted 2009-09-23
}

thereby increasing adenylate cyclase activity and cAMP accumulation $^{[4]}$. On the other hand, $\beta_{2}$-AR agonists can prime the glucocorticoid receptor for steroid-dependent activation, enhance glucocorticoid-dependent transcription and inhibit transcription of inflammatory factors such as NF- $\mathrm{KB}^{[5-7]}$.

Glycyrrhizin (GL), a major and active constituent of licorice root, has many attributed pharmacological effects, including anti-inflammatory ${ }^{[8]}$, anti-allergy ${ }^{[9]}$, and anti-viral activities $^{[10]}$, which may be due to the steroid-like structure of $18 \beta$-glycyrrhetinic acid. Therefore, we hypothesized that GL could interact with $\beta_{2}$-AR agonists at both the molecular and receptor level in a manner similar to glucocorticoids. Cotreatment with GL and a $\beta_{2}$-AR agonist would yield synergistic anti-asthmatic effects, thereby increasing $\beta_{2}$-AR agonist bronchodilation activity and yielding complementary antiinflammatory effects. The potential of substituting GL for glucocorticoids in combination with $\beta_{2}$-AR agonists in the treatment of asthma was investigated.

To address these hypotheses, the effect of GL on $\beta_{2}$-ARs and $\beta_{2}$-AR activity was evaluated by examining the effect of GL on $\beta_{2}$-AR mRNA levels, salbutamol (SA)-induced cAMP 
accumulation and relaxation of guinea pig tracheal strips. Anti-inflammatory effects induced by GL and a $\beta_{2}$-AR agonist were evaluated via TNF- $\alpha$-stimulated NF-KB transcription factor activation levels and Western blotting analysis of NF-KB inhibitor (I-kBa) degradation. The inhibition of NF-kB-related inflammation was further investigated by testing interleukin-8 (IL-8) production in pulmonary cells. To further investigate the synergy of GL and SA, their combined effect was assessed in vivo using the guinea pig asthma model. This study provides a foundation and molecular rationale for continuing research on the potential therapeutic applicability of GL and $\beta_{2}$-AR agonist combined treatment of bronchial asthma.

\section{Materials and methods Materials}

Glycyrrhizin (GL) was purchased from Tianjin Institute of Drug Control (Tianjin, China). Salbutamol (SA), dexamethasone (DEX), and propranolol (PRO) were purchased from Sigma Chemical Co (St Louis, MO, USA). Other reagents used in this study were of analytical grade and commercially available. Polyclonal anti-I-kBa, anti-actin, and secondary horseradish peroxidase-conjugated anti-rabbit antibodies were purchased from Santa Cruz Biotechnology (San Diego, CA, USA).

\section{Cell culture}

CHO- $\beta_{2}$-AR-CRE-EGFP cells, human embryonic kidney 293 (HEK293) cells, NIH-3T3 cells, and A549 cells were grown in Dulbecco's modified Eagle's medium (DMEM) containing $10 \%$ fetal bovine serum (FBS), $100 \mathrm{U} / \mathrm{mL}$ of penicillin, and 0.1 $\mathrm{mg} / \mathrm{mL}$ of streptomycin, and were maintained at $37^{\circ} \mathrm{C}$ in $5 \%$ $\mathrm{CO}_{2}$. All reagents were purchased from GibcoBRL Life Technologies (Rockville, MD, USA). Human bronchial smooth muscle cells (hBSMCs) were cultured in smooth muscle cell medium (SMCM) at $37^{\circ} \mathrm{C}$ in $5 \% \mathrm{CO}_{2}$. hBSMCs and SMCM were purchased from ScienCell Research Laboratories (Carlsbad, CA, USA).

\section{Animals}

Male Hartley guinea pigs (300-500 g) and Wistar rats (300-400 g) were provided by the Academy of Military Medical Science (Beijing, China). All experimental protocols were approved by the Committee of Animal Care of Nankai University (Tianjin, China). Animals were bred in an animal facility under controlled temperature $\left(20^{\circ} \mathrm{C}\right)$, relative humidity $(50 \%)$ and light (14:10 h, light:dark cycle) conditions, with free access to food and water.

\section{Real-time RT PCR of $\beta_{2}$-AR mRNA in rat lung}

Twelve rats were divided into four groups and exposed to inhaled atomized physiological saline, $0.1 \mu \mathrm{mol} / \mathrm{L} \mathrm{SA}, 0.3$ $\mu \mathrm{mol} / \mathrm{L} \mathrm{GL}$, or $0.1 \mu \mathrm{mol} / \mathrm{L} \mathrm{SA}$ and $0.3 \mu \mathrm{mol} / \mathrm{L}$ GL for $2 \mathrm{~min}$ twice a day for $7 \mathrm{~d}$. Total cell RNA was isolated from rat lung using the SV Total RNA Isolation System (Promega, Madison, WI, USA) following the manufacturer's protocols. Total RNA was reverse-transcribed using the Reverse Transcription
System (Promega, Madison, WI, USA). Quantitative RT-PCR was performed for $\beta_{2}$-AR mRNA with SYBRGreen (Toyobo Co, Ltd, Osaka, Japan). Results were normalized to the housekeeping gene GAPDH. Primers for $\beta_{2}$-AR were: forward 5'-ACCTCCTTCTTGCCTATCCA-3' and reverse 5'-TAGGTTTTCGAAGAAGACCG-3'. Primers for GAPDH were: forward 5'-CCACCCATGGCAAATTCCATGGCA-3' and reverse 5'-TCTAGACGGCAGGTCAGGTCCAC-3'. GAPDH was used as an internal control. Beta2-AR mRNA levels were compared among drug-treated and negative controls. Gene expression was evaluated with threshold cycles using the $2^{-\Delta \Delta C T}$ method $^{[11]}$. The PCR product specificity was confirmed by a melting curve. Experiments were performed in triplicate.

\section{cAMP-regulated reporter gene assay}

The CHO- $\beta_{2}$-AR-CRE-EGFP cell line was constructed and cultured as previously described ${ }^{[12]}$. Briefly, this cell line expressed exogenous $\beta_{2}$-AR and contains a cAMP-regulated EGFP reporter gene. When the cells were stimulated by $\beta_{2}$-AR agonists, the increase of intracellular cAMP induced the expression of EGFP. The cells were treated with different drug combinations in 12-well plates. Drug-treated cells were trypsinized, washed and resuspended in PBS (0.01 $\mathrm{mol} / \mathrm{L}$ ) containing $2 \% \mathrm{FBS}$. The number of green fluorescent protein(GFP)-positive cells per ten thousand cells was measured using a FACS Calibur flow cytometer (Becton Dickinson, Franklin Lakes, NJ, USA), equipped and analyzed using CellQuest software (Becton Dickinson). All experiments were performed in triplicate, and results were expressed as mean \pm SEM and analyzed with the GraphPad Prism 4.0 program (GraphPad Software, San Diego, CA, USA).

\section{The isolated guinea pig tracheal strips relaxation model}

Hartley strain guinea pigs were sacrificed with an overdose of pentobarbital $(75 \mathrm{mg} / \mathrm{kg}$, ip). Tracheal strips were removed and manipulated as previously described ${ }^{[12]}$. Acetylcholine (ACh) was added to the organ bath to induce the contraction of smooth muscle. SA, GL, and DEX were added to the organ bath 10 min before the addition of ACh. PRO was added $10 \mathrm{~min}$ before the addition of SA, GL, and DEX. The peak contractile response was designated as $100 \%$. Tension was expressed as a percentage of the peak contractile response.

\section{Transient transfection and luciferase assay}

The NF-KB-responsive luciferase reporter constructed with IgK2-IFN-LUC was established as previously described ${ }^{[13]}$. Transient transfection with IgK2-IFN-LUC was performed using the Lipofectamine 2000 reagent (Invitrogen, Carlsbad, CA, USA) in accordance with the manufacturer's recommendations. HEK 293 cells were treated for $6 \mathrm{~h}$ with drug combinations $24 \mathrm{~h}$ after transfection and harvested for the detection of luciferase activity using a Lumat LB9507 luminometer (EG\&G Berthold, Oak Ridge, TN, USA) and Dual Luciferase Assay kits (Promega, San Luis Obispo, CA, USA). Co-transfection with pRL-TK (Promega), which expresses Renilla luciferase, served to normalize the data and account for transfection efficiency. 


\section{Western blotting of I-KB $\alpha$}

NIH-3T3 cells were lysed in lysate buffer $(20 \mathrm{mmol} / \mathrm{L}$ Tris$\mathrm{HCl}, \mathrm{pH} 7.5,1 \%$ Triton $\mathrm{X}-100,137 \mathrm{mmol} / \mathrm{L}$ sodium chloride, $10 \%$ glycerol, $2 \mathrm{mmol} / \mathrm{L}$ EDTA, $1 \mathrm{mmol} / \mathrm{L}$ sodium orthovanadate, $25 \mathrm{mmol} / \mathrm{L} \beta$-glycerophosphate, $2 \mathrm{mmol} / \mathrm{L}$ sodium pyrophosphate, $1 \mathrm{mmol} / \mathrm{L}$ phenylmethylsulphonyl fluoride and $1 \mathrm{mg} / \mathrm{mL}$ leupeptin). A polyclonal I-kBa antibody (1:500) was used to assess I-kBa levels, and proteins of interest were visualized using Western Blotting Luminol Reagent (Santa Cruz Biotechnology, San Diego, CA, USA). Equal protein loading was verified by actin immunoblot. A minimum of three separate experiments were performed.

\section{Enzyme-linked immunosorbent assay (ELISA) of IL-8}

A549 cells and hBSMCs were pre-incubated with the tested drugs for $1 \mathrm{~h}$ and continuously incubated with TNF-a for $6 \mathrm{~h}$. IL-8 levels in the culture medium were quantified by ELISA using an anti-IL-8 antibody according to the manufacture's instructions (R\&D Systems, Minneapolis, MN, USA).

\section{In vivo bronchial hyperreactivity test}

Thirty-five male Hartley strain guinea pigs were divided into five treatment groups. During the experiment, animals were manipulated as previously described ${ }^{[12]}$. Briefly, the animals were placed in an inhalation cage, and each animal was exposed to atomized $0.1 \%$ histamine solutions for $20 \mathrm{~s}$ at the rate of $0.8 \mathrm{~mL} / \mathrm{min}$. The animals were withdrawn from the inhalation cage, and the time until the appearance of asphyxial convulsions was measured as the latent period of asthma. Two days after the first treatment, animals were exposed a second time using this identical procedure. Asthma latency period of each animal was calculated as the ratio of increased latency time to the original latency time by Vogel's method ${ }^{[14]}$. Normal saline served as a vehicle control.

\section{Statistical analysis}

Data are presented as mean \pm SEM. Statistical analysis of the data for multiple comparisons was carried out by ANOVA followed by the Bonferroni post hoc test. For single comparisons, significance differences between means were determined by Student's $t$-test. Statistical significance was set at $P<0.01$.

\section{Results}

GL modulates $\beta_{2}$-AR function by increasing $\beta_{2}$-AR mRNA levels and SA-stimulated cAMP accumulation

The effects of GL on $\beta_{2}$-AR and $\beta_{2}$-AR activity were evaluated by examining the effects of GL on $\beta_{2}$-AR mRNA levels and SA-stimulated CAMP accumulation. As shown in Figure 1, inhaled $0.3 \mu \mathrm{mol} / \mathrm{L}$ GL significantly increased $\beta_{2}$-AR mRNA levels $(47 \% \pm 0.27 \%$ of untreated control), while $0.1 \mu \mathrm{mol} / \mathrm{LSA}$ treatment alone reduced $\beta_{2}$-AR mRNA levels $(56 \% \pm 0.12 \%$ of untreated control). Despite a modest decrease $(12 \% \pm 0.08 \%$ of untreated control), combined treatment of SA and GL did not significantly alter $\beta_{2}$-AR mRNA levels in rat lungs. However, the combination resulted in a significant decrease compared to the $0.3 \mu \mathrm{mol} / \mathrm{L}$ GL dose alone.

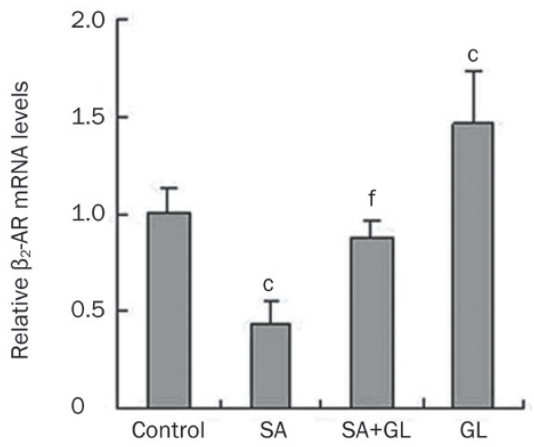

Figure 1. Effects of GL on increasing $\beta_{2}-A R$ mRNA levels. Animals inhaled atomized physiological saline (control), $0.1 \mu \mathrm{mol} / \mathrm{L}$ salbutamol (SA), 0.3 $\mu \mathrm{mol} / \mathrm{L}$ glycyrrhizin (GL), or $0.1 \mu \mathrm{mol} / \mathrm{L} \mathrm{SA}$ and $0.3 \mu \mathrm{mol} / \mathrm{L} \mathrm{GL}(\mathrm{SA}+\mathrm{GL}$ ) twice a day, for $7 \mathrm{~d}$. Mean \pm SEM. $n=3$. ${ }^{c} P<0.01$ vs the saline control group. ${ }^{f} P<0.01$ vs the $0.3 \mu \mathrm{mol} / \mathrm{L} \mathrm{GL}$ group.

CHO- $32-A R-C R E-E G F P$ cells were treated with different concentrations of GL and SA alone or a combination of 0.3 $\mu \mathrm{mol} / \mathrm{L} \mathrm{GL}$ and SA in various concentrations. As shown in the dose-response curve displayed in Figure $2 \mathrm{~A}$, the $\mathrm{EC}_{50}$ of SA was $5.1 \pm 0.9 \mathrm{nmol} / \mathrm{L}$. GL was unable to stimulate reporter gene expression, but it shifted the curve left when administered in combination with SA. The $\mathrm{EC}_{50}$ was $0.73 \pm 0.12 \mathrm{nmol} / \mathrm{L}$ and was significantly reduced compared to SA alone. In another experiment, the time course of SA- and GL-stimulated reporter gene expression in $\mathrm{CHO}-\beta_{2}$-AR-CRE-EGFP cells was
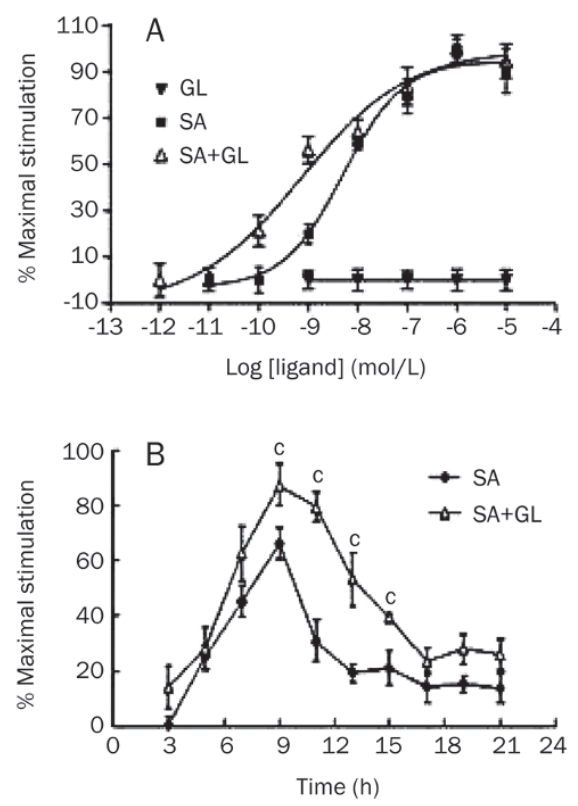

Figure 2. Effects of GL on increasing salbutamol (SA)-stimulated cAMP accumulation. (A) Dose-response curve of $\mathrm{CHO}-\beta_{2}-\mathrm{AR}-\mathrm{CRE}-\mathrm{GFP}$ cells stimulated by different concentrations of $\mathrm{GL}$ or $\mathrm{SA}$ alone, or $0.3 \mu \mathrm{mol} / \mathrm{L}$ $\mathrm{GL}$ administered in concert with different $\mathrm{SA}$ concentrations (SA+GL). (B) The time course of $0.01 \mu \mathrm{mol} / \mathrm{L} S A$ and $0.3 \mu \mathrm{mol} / \mathrm{L} \mathrm{GL}$ stimulated reporter gene expression in $\mathrm{CHO}-\beta_{2}-\mathrm{AR}-\mathrm{CRE}-\mathrm{GFP}$ cells. Mean \pm SEM. $n=3 .{ }^{\mathrm{c}} P<0.01$ vs $0.01 \mu \mathrm{mol} / \mathrm{L}$ SA treated group. 
evaluated. As shown in Figure 2B, when activated by 0.01 $\mu \mathrm{mol} / \mathrm{L} \mathrm{SA}$ alone, intensity of EGFP peaked at approximately $9 \mathrm{~h}$. However, the activity was significantly increased when administered in combination with GL $(0.3 \mu \mathrm{mol} / \mathrm{L})$ for $9-15$ h. Because reporter gene expression level was indicative of intracellular cAMP, the results suggest that GL increased SAstimulated adenylate cyclase activity and cAMP accumulation.

\section{Glycyrrhizin enhances the relaxing effect of SA on isolated} guinea pig tracheal strips

The ability of the SA and GL combination to enhance the relaxing effect on Ach-induced contraction of guinea pig tracheae was compared with that of the effect of the positive control drug, SA, alone. As shown in Figure 3, SA administration resulted in a concentration-dependent relaxation of Achinduced contracted tracheal muscle, with $0.001,0.01$, and 0.1 $\mu \mathrm{mol} / \mathrm{L}$ SA eliciting $\mathrm{EC}_{50}$ values of $7.303 \pm 0.015,16.28 \pm 0.21$, and $66.61 \pm 0.33 \mu \mathrm{mol} / \mathrm{L}$, respectively (Table 1 ). GL alone failed to yield a significant anti-Ach effect. However, addition of 0.003

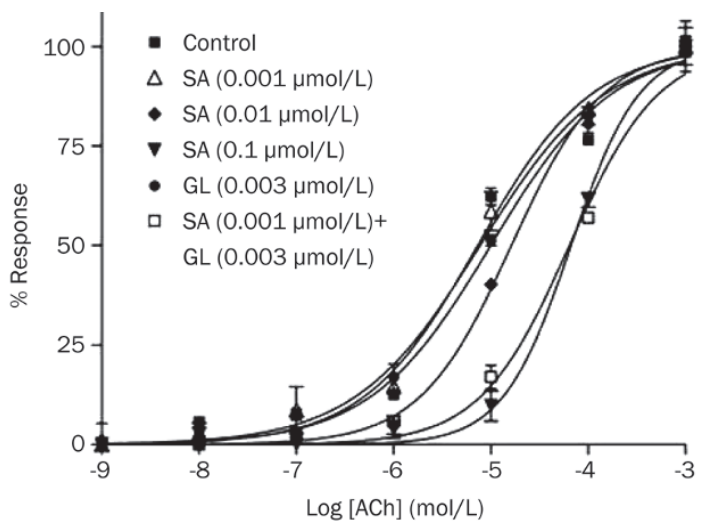

Figure 3. Effects of $G L$ on enhancing the relaxing effect of $\beta_{2}-A R$ agonists in isolated guinea pig tracheal strips. Tension is expressed as a percentage of the peak contractile response, which was assigned as $100 \%$. Mean \pm SEM. $n=3$.

Table 1. $E C_{50}$ values of concentration-response curve of acethylcholine induced tracheal contractions. ${ }^{\mathrm{c}} P<0.01$ vs control. ${ }^{\mathrm{f}} P<0.01$ vs $\mathrm{GL}$ alone group. Mean \pm SEM. $n=3$.

\begin{tabular}{lll}
\hline & Concentration $(\mu \mathrm{mol} / \mathrm{L})$ & $\mathrm{EC}_{50}(\mu \mathrm{mol} / \mathrm{L})$ \\
\hline Control & $/$ & $7.740 \pm 0.021$ \\
$\mathrm{SA}$ & 0.001 & $7.303 \pm 0.015$ \\
& 0.01 & $16.28 \pm 0.21^{\mathrm{c}}$ \\
& 0.1 & $66.61 \pm 0.33^{\mathrm{c}}$ \\
$\mathrm{PRO}+\mathrm{SA}$ & $0.1+0.01$ & $8.212 \pm 0.007$ \\
$\mathrm{GL}$ & 0.003 & $9.957 \pm 0.090$ \\
$\mathrm{GL}+\mathrm{SA}$ & $0.003+0.001$ & $63.99 \pm 0.42^{\mathrm{cf}}$ \\
PRO+GL+SA & $0.1+0.003+0.001$ & $10.28 \pm 0.92$ \\
DEX & 0.001 & $9.030 \pm 0.020$ \\
DEX+SA & $0.001+0.001$ & $60.45 \pm 0.11^{\circ}$ \\
PRO+DEX+SA & $0.1+0.001+0.001$ & $7.369 \pm 0.032$ \\
\hline
\end{tabular}

SA, salbutamol; GL, glycyrrhizin; DEX, dexamethasone; PRO, propranolol. $\mu \mathrm{mol} / \mathrm{L}$ GL in combination with $0.001 \mu \mathrm{mol} / \mathrm{LSA}$ resulted in a significantly higher relaxation effect, approximately as high as that of 100-fold concentrated SA alone. In other words, the combination of $0.001 \mu \mathrm{mol} / \mathrm{LSA}$ and $0.003 \mu \mathrm{mol} / \mathrm{L} \mathrm{GL}$ showed a potency similar to $0.1 \mu \mathrm{mol} / \mathrm{L} \mathrm{SA}$. PRO is a nonselective $\beta$-AR antagonist that has been shown to block the activation of $\beta_{2}$-AR. As shown in Table 1, PRO blocked the tracheal muscle relaxation stimulated by SA. When the $\beta_{2}$-AR was blocked, the ability of GL to enhance SA was also blocked. Effects observed with the positive control, $0.001 \mu \mathrm{mol} / \mathrm{L} \mathrm{DEX,}$ were similar to those observed with GL (Table 1).

\section{Combined GL and SA treatment promotes anti-inflammatory activity}

The anti-inflammatory activity of the combination of GL and SA was examined using ELISA and Western blotting.

HEK293 cells transfected with IgK2-IFN-LUC significantly inhibited NF- $\mathrm{kB}$ promoter activation by $35 \% \pm 3.5 \%$ and $40 \% \pm 4.8 \%$, respectively. Combined treatment had an additive inhibitive effect of $70 \% \pm 7.4 \%$.

NIH-3T3 cells were treated prior to TNF-a stimulation for $1 \mathrm{~h}$ with $0.01 \mu \mathrm{mol} / \mathrm{L} \mathrm{GL}, 0.01 \mu \mathrm{mol} / \mathrm{L} \mathrm{SA}$, or a combination of both drugs, and were assessed in a time-course experiment. As shown in Figure 4B, I-KBa was fully degraded after a 20 min incubation with TNF-a but gradually regenerated over a 30 min period in negative controls. Pretreatment with SA, GL,

A
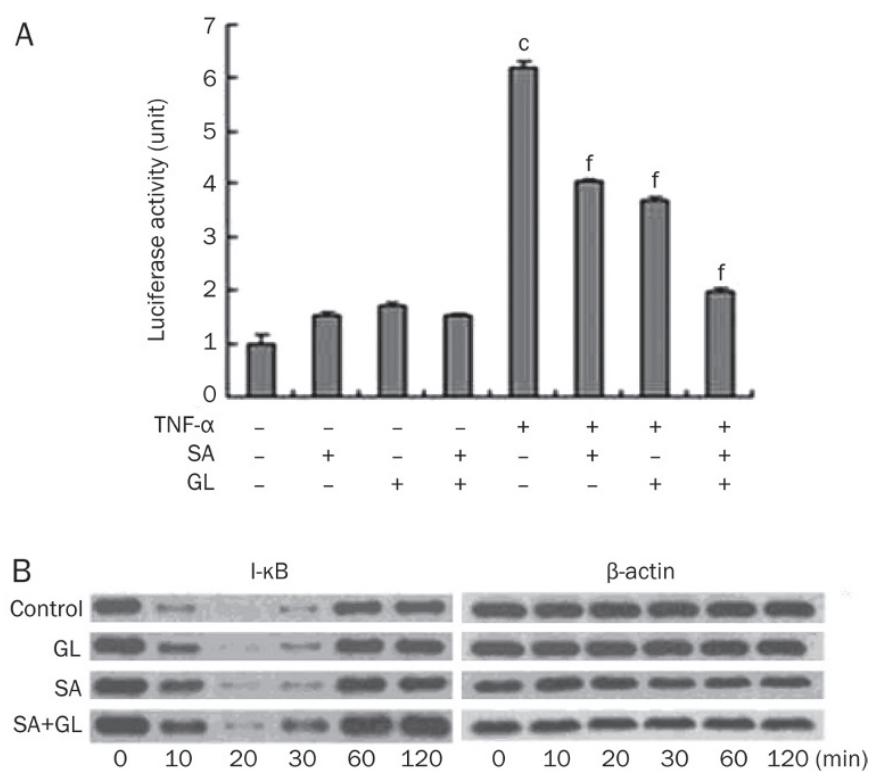

Figure 4. Effects of $G L$ and $S A$ on inhibiting TNF- $\alpha$-induced NF-KB activation. (A) After transfected with IgK2-IFN-LUC and pRL-TK plasmids, HEK293 cells in different groups were treated with $10 \mathrm{ng} / \mathrm{mL}$ TNF- $\alpha$, $0.01 \mu \mathrm{mol} / \mathrm{L} \mathrm{SA}$ or $0.01 \mu \mathrm{mol} / \mathrm{L} \mathrm{GL}$ for $6 \mathrm{~h}$. The luciferase activity was expressed as the ratio of firefly to renilla luminescence. Mean \pm SEM. $n=3 .{ }^{~} P<0.01$ vs control without any stimulation. ${ }^{f} P<0.01$ vs the TNF- $\alpha-$ activated group. (B) NIH-3T3 cells, treated with $0.01 \mu \mathrm{mol} / \mathrm{L} \mathrm{GL}, 0.01$ $\mu \mathrm{mol} / \mathrm{LSA}$ or the combination, were then stimulated by $10 \mathrm{ng} / \mathrm{mL}$ TNF- $\alpha$. The time course of I-KB $\alpha$ protein degradation was analyzed by Western blot. Three separate experiments confirmed observed changes. 
or a combination suppressed I-kBa protein degradation, and at 30 min the combination treatment showed a more pronounced effect than the other treatment groups. In other words, the regeneration rate of the combination group is faster than that of either the GL- or SA-alone group; thus, the combination treatment displays an additive effect.

IL-8 protein levels in spent culture media of A549 cells and hBSMCs treated with TNF-a were measured by ELISA to assess the effect of combined SA and GL treatment. As shown in Figure 5A and 5B, IL-8 levels in TNF-a-treated medium were significantly greater compared to the negative control. Pretreatment with $0.1 \mathrm{mmol} / \mathrm{L} \mathrm{SA}, 0.01 \mathrm{mmol} / \mathrm{L}$ DEX or a combination of both markedly blocked TNF-a-mediated IL-8 release. GL treatment $(0.1 \mathrm{mmol} / \mathrm{L})$ alone or in combination with SA also blocked the increase in IL-8 release. GL and SA co-treatment resulted in the most pronounced inhibition compared to the TNF-a-activated group and significantly differed from the GL-alone group.

\section{SA and GL synergy in the in vivo bronchial hyper-reactivity test}

To confirm the synergistic effect of SA and GL in an in vivo
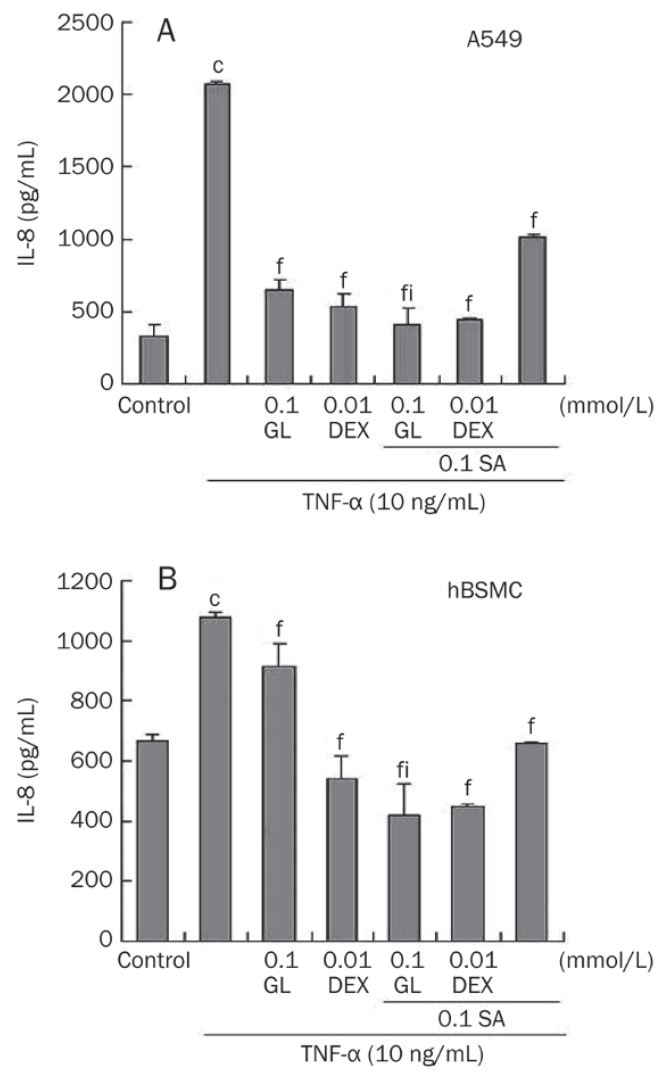

Figure 5. Effects of GL and SA on inhibiting TNF- $\alpha$ mediated IL-8 production. A549 cells (A) or human bronchial smooth muscle cells (HBSMC). (B) were incubated with $0.1 \mathrm{mmol} / \mathrm{L} \mathrm{SA}, 0.1 \mathrm{mmol} / \mathrm{L} \mathrm{GL}, 0.01 \mathrm{mmol} / \mathrm{L}$ dexamethasone (DEX) or their combinations for $1 \mathrm{~h}$, in concert with 10 $\mathrm{ng} / \mathrm{mL}$ TNF- $\alpha$ incubation for $6 \mathrm{~h}$. IL-8 levels in culture medium were assessed by ELISA. Each bar represents the mean \pm SEM. $n=3 .{ }^{c} P<0.01$ vs control without any stimulation. ${ }^{f} P<0.01$ vs the TNF- $\alpha$-activated group. ' $P<0.01$ vs the $0.1 \mathrm{mmol} / \mathrm{L} \mathrm{GL}$ group. model, guinea pigs inhaled atomized physiological saline, 0.1 $\mu \mathrm{mol} / \mathrm{L}$ SA, $1.0 \mu \mathrm{mol} / \mathrm{LSA}, 0.3 \mu \mathrm{mol} / \mathrm{L}$ GL, or $0.1 \mu \mathrm{mol} / \mathrm{LSA}$ and $0.3 \mu \mathrm{mol} / \mathrm{L} \mathrm{GL}$ two days after initial exposure to histamine. Animals were then exposed to histamine a second time. As shown in Figure 6, the latent period increased (1.1 \pm 0.32$)$ fold in the $0.1 \mu \mathrm{mol} / \mathrm{L}$ SA-treated group. GL alone failed to elicit a significant effect in the asthma model. However, when $0.3 \mu \mathrm{mol} / \mathrm{L}$ GL was administered in concert with $0.1 \mu \mathrm{mol} / \mathrm{L}$ SA, a significant increase (2.2 \pm 0.35$)$-fold was observed similar to that observed with a 10-fold higher SA concentration [1.0 $\mu \mathrm{mol} / \mathrm{L},(2.1 \pm 0.42)$ fold]. These data provide in vivo evidence for SA and GL synergy.

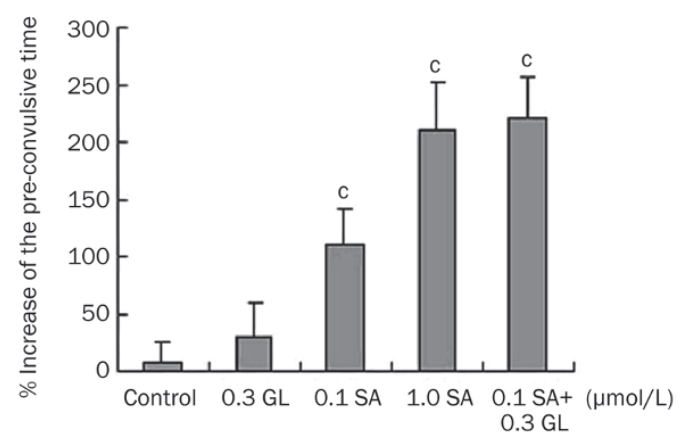

Figure 6. Synergistic anti-asthmatic effects of salbutamol (SA) and glycyrrhizin (GL) in the atomized histamine asthma induced guinea pig model. Animals were exposed to atomized $0.1 \%$ histamine solutions for $20 \mathrm{~s}$. After a two day interval exposure to $0.1 \mu \mathrm{mol} / \mathrm{L} \mathrm{SA}, 1.0 \mu \mathrm{mol} / \mathrm{L} \mathrm{SA}, 0.3$ $\mu \mathrm{mol} / \mathrm{L} \mathrm{GL}$, or $0.3 \mu \mathrm{mol} / \mathrm{L} \mathrm{GL}$ and $0.1 \mu \mathrm{mol} / \mathrm{L}$ SA occurred immediately prior to the second $0.1 \%$ histamine solution exposure. Asthma latency period increasing rate of each animal was presented as the ratio of increased time to the original latency time. Each bar represents the mean \pm SEM. $n=7$. ${ }^{c} P<0.01$ vs control.

\section{Discussion}

Glycyrrhizin (GL) is a triterpene glycoside that consists of a glycyrrhetic acid molecule and two glucuronic acid molecules located at the C-3 position. GL itself has a glucocorticoid-like action $^{[15,16]}$ and holds promise as an alternative to steroid treatment with a similar potency when used in combination with a $\beta_{2}$-AR agonist.

Corticosteroids modulate $\beta_{2}$-AR via many different mechanisms, including stimulating the transcription of the $\beta_{2}-A R$ and increasing the efficiency of coupling between $\beta_{2}$-AR and $\mathrm{G}_{\mathrm{s}}{ }^{44]}$. In the present study, we hypothesized that GL could have a function similar to dexamethasone, which has been shown to increase $\beta_{2}$-AR mRNA and protein levels in lung ${ }^{[3]}$. As observed in $\beta_{2}$-AR mRNA quantification assays and cAMPregulated reporter gene experiments, GL is capable of increasing $\beta_{2}$-AR mRNA levels and SA-induced cAMP accumulation. These results support the hypothesis that the combination of SA and GL could have a synergistic effect on the activity of $\beta_{2}$-ARs. In the same assays, we identified that, in addition to $\mathrm{SA}$, other $\beta_{2}$-AR agonists, such as epinephrine, isoproterenol 
and ephedrine, had the same synergistic effect with GL. The $\mathrm{EC}_{50} \mathrm{~s}$ of these $\beta_{2}-\mathrm{AR}$ agonists were decreased 3.36- to 9.1-fold by the addition of GL (data not shown).

Although the pathophysiology of asthma is complex and multifactorial, airflow limitation is the principal characteristic of the disease, with all $\beta_{2}$-AR agonists exerting therapeutic effects via cell surface $\beta_{2}$-ARs in the airway. One of the major functions of $\beta_{2}$-AR agonists is airway smooth muscle relaxation. Thus, to further demonstrate the synergistic antiasthma effect of SA and GL, their effects on isolated guinea pig tracheal strips and in vivo guinea pig model were evaluated. Although GL had no effect when administered alone, SA was more powerful in relaxing contractive airway and reducing the severity of bronchoconstriction and asphyxial convulsions induced by atomized histamine when administrated with GL. This result raises the possibility of combining GL with $\beta_{2}$-AR agonists in the treatment of asthma.

Asthma is a chronic inflammatory airway disease involving multiple complex pathways. In asthma NF- $\mathrm{kB}$ is markedly activated, which in turn regulates many inflammatory genes that are abnormally expressed ${ }^{[17]}$. In the NF-kB pathway, TNF- $\alpha$ activates I- $\mathrm{kB}$ kinases, which induces the subsequent degradation of I-kBa. Then, the NF-kB component, p65, translocates from the cytoplasm to the nucleus and activates transcription of target genes ${ }^{[18]}$, including the important inflammatory mediator IL-8. Glucocorticoids can inhibit IL-8 production $^{[19]}$ via inhibition of NF-KB ${ }^{[20]}$. While it has been reported that GL inhibits NF-KB activity in lung epithelial cells ${ }^{[15]}$, data reported here include the combined additive effect of $S A$ and GL on TNF- $\alpha$ induced NF-kB activation. Western blotting analysis of $\mathrm{I}-\mathrm{kBa}$ protein (Figure $3 \mathrm{~B}$ ) revealed that the inhibitory effect of SA and GL on TNF-a-induced activation of NF- $\mathrm{kB}$ activity was attributable to inhibited I- $\mathrm{kB}$ kinase activity. Inhibition of IL-8 production in pulmonary cells was significantly greater when the two drugs were combined. Thus, the interaction among SA and GL may result in complementary anti-inflammatory effects in the airway.

Because of the chronic nature of asthma, long-term medications are required for asthma therapy. The combination of $\beta_{2}$-AR agonists and glucocorticoids is more efficacious for asthma than either alone or in other combination therapies ${ }^{[21]}$. Despite their effectiveness, the use of glucocorticoids in lung diseases is limited due to severe side effects ${ }^{[22]}$. Therefore, discovery of non-steroidal drugs that can be administered longterm without adverse effects is imperative. GL, a natural compound, does not provide any evidence of chronic toxicity or tumorigenicity with long-term daily administration in mice ${ }^{[23]}$, nor is it teratogenic in rats ${ }^{[2]}$. The acceptable daily GL intake is reported to be $0.015-0.229 \mathrm{mg} / \mathrm{kg}$ body weight per day ${ }^{[25]}$. It has been reported that GL has the ability to prevent nitrogen species-mediated lung cell damage ${ }^{[26]}$. Considering the therapeutic potential of GL, the results reported here demonstrate the important pharmacology of GL in combination with a $\beta_{2}$-AR agonist, offering the possibility of therapeutic application in the treatment of asthma.

\section{Acknowledgements}

The work was supported in part by the National High Technology Research and Development Program of China (863 Program, No 2006 AA020502), and Grant No 07JCZDJC05000 from the Natural Science Foundation of Tianjin, China.

\section{Author contribution}

Gang BAI designed the research; Yang YANG, Qian SHI, Ze LIU, Ruo-jie LI and Peng-wei PAN performed the research; Wan-ge LU contributed the new analytical tools and reagents; Yuan-yuan HOU analyzed the data.

\section{References}

1 Bousquet J, Jeffery PK, Busse WW, Johnson M, Vignola AM. Asthma. From bronchoconstriction to airways inflammation and remodeling. Am J Respir Crit Care Med 2000; 161: 1720-45.

2 Johnson M. Corticosteroids: potential beta2-agonist and anticholinergic interactions in chronic obstructive pulmonary disease. Proc Am Thorac Soc 2005; 2: 320-5; discussion 340-1.

3 Mak JC, Nishikawa M, Barnes PJ. Glucocorticosteroids increase beta2-adrenergic receptor transcription in human lung. Am J Physiol 1995; 268: L41-6.

4 Mak JC, Nishikawa M, Shirasaki H, Miyayasu K, Barnes PJ. Protective effects of a glucocorticoid on downregulation of pulmonary beta2adrenergic receptors in vivo. J Clin Invest 1995; 96: 99-106.

5 Adcock IM, Maneechotesuwan K, Usmani O. Molecular interactions between glucocorticoids and long-acting beta2-agonists. J Allergy Clin Immunol 2002; 110: S261-8.

6 Ammit AJ, Lazaar AL, Irani C, O'Neill GM, Gordon ND, Amrani Y, et al. Tumor necrosis factor-alpha-induced secretion of RANTES and interleukin- 6 from human airway smooth muscle cells: modulation by glucocorticoids and beta-agonists. Am J Respir Cell Mol Biol 2002; 26: 465-74.

7 Kaur M, Chivers JE, Giembycz MA, Newton R. Long-acting beta2adrenoceptor agonists synergistically enhance glucocorticoiddependent transcription in human airway epithelial and smooth muscle cells. Mol Pharmacol 2008; 73: 203-14.

8 Kim YW, Zhao RJ, Park SJ, Lee JR, Cho IJ, Yang CH, et al. Antiinflammatory effects of liquiritigenin as a consequence of the inhibition of NF-kappaB-dependent iNOS and proinflammatory cytokines production. Br J Pharmacol 2008; 154: 165-73.

9 Ram A, Mabalirajan U, Das M, Bhattacharya I, Dinda AK, Gangal SV, et al. Glycyrrhizin alleviates experimental allergic asthma in mice. Int Immunopharmacol 2006; 6: 1468-77.

10 Harada S. The broad anti-viral agent glycyrrhizin directly modulates the fluidity of plasma membrane and HIV-1 envelope. Biochem J 2005; 392: 191-9.

11 Livak KJ, Schmittgen TD. Analysis of relative gene expression data using real-time quantitative PCR and the $2^{-\Delta \Delta C T}$ method. Methods 2001; 25: 402-8.

12 Bai G, Yang Y, Shi Q, Liu Z, Zhang Q, Zhu YY. Identification of higenamine in Radix Aconiti Lateralis Preparata as a beta2-adrenergic receptor agonist. Acta Pharmacol Sin 2008; 29: 1187-94.

13 Pomerantz JL, Denny EM, Baltimore D. CARD11 mediates factorspecific activation of NF-kappaB by the T cell receptor complex. EMBO J 2002; 21: 5184-94.

14 Vogel HG VW. Drug Discovery and Evaluation: Pharmacological Assay. 2nd ed. Springer-Verlag Berlin Heidelberg; 1997.

15 Takei H, Baba Y, Hisatsune A, Katsuki H, Miyata T, Yokomizo K, et 
al. Glycyrrhizin inhibits interleukin-8 production and nuclear factorkappaB activity in lung epithelial cells, but not through glucocorticoid receptors. J Pharmacol Sci 2008; 106: 460-8.

16 Yoh T, Nakashima T, Sumida Y, Kakisaka Y, Nakajima Y, Ishikawa H, et al. Effects of glycyrrhizin on glucocorticoid signaling pathway in hepatocytes. Dig Dis Sci 2002; 47: 1775-81.

17 Barnes PJ, Adcock IM. Transcription factors and asthma. Eur Respir J 1998; 12: 221-34.

18 Ghosh S, Karin M. Missing pieces in the NF-kappaB puzzle. Cell 2002; 109: S81-96.

19 Fitzgerald DC, Meade KG, McEvoy AN, Lillis L, Murphy EP, Machugh $\mathrm{DE}$, et al. Tumour necrosis factor-alpha (TNF-alpha) increases nuclear factor kappaB (NFkappaB) activity in and interleukin-8 (IL-8) release from bovine mammary epithelial cells. Vet Immunol Immunopathol 2007; 116: 59-68.

20 King EM, Holden NS, Gong W, Rider CF, Newton R. Inhibition of NFkappaB-dependent transcription by MKP-1: transcriptional repression by glucocorticoids occurring via p38 MAPK. J Biol Chem 2009; 284: 26803-15.
21 Johnson M. Interactions between corticosteroids and beta2-agonists in asthma and chronic obstructive pulmonary disease. Proc Am Thorac Soc 2004; 1: 200-6.

22 Huscher D, Thiele K, Gromnica-Ihle E, Hein G, Demary W, Dreher R, et al. Dose-related patterns of glucocorticoid-induced side effects. Ann Rheum Dis 2009; 68: 1119-24.

23 Kobuke T, Inai K, Nambu S, Ohe K, Takemoto T, Matsuki K, et al. Tumorigenicity study of disodium glycyrrhizinate administered orally to mice. Food Chem Toxicol 1985; 23: 979-83.

24 Itami T, Ema M, Kanoh S. Effect of disodium glycyrrhizinate on pregnant rats and their offspring. J Food Hyg Soc Jpn 1985; 26 : 460-4.

25 Isbrucker RA, Burdock GA. Risk and safety assessment on the consumption of Licorice root (Glycyrrhiza $\mathrm{sp}$ ), its extract and powder as a food ingredient, with emphasis on the pharmacology and toxicology of glycyrrhizin. Regul Toxicol Pharmacol 2006; 46: 167-92.

26 Lee CS, Kim YJ, Han ES. Glycyrrhizin protection against 3-morpholinosydnonime-induced mitochondrial dysfunction and cell death in lung epithelial cells. Life Sci 2007; 80: 1759-67.

\title{
World Drug Safety Congress Americas 2010
}

\author{
Washington DC, United States \\ 20-23 Apr 2010
}

Organizer: Health Network Communications

Website: www.healthnetworkcommunications.com/2010/safetyusa

Contact: Miss Katie Barden, Welken House 10-11 Charterhouse Square

London EC1M 6EH United Kingdom; phone: (+44 (0) 207608 7055) 